\title{
Effect of Straw Disposal Method and of Nitrogen Rates on Rice Yields and Recovery of Fertilizer Nitrogen ${ }^{1}$
}

\author{
José Lozano, José Vicente-Chandler and Fernando Abruña ${ }^{2,3}$
}

ABSTRACT

Burning, plowing or removing straw from the fields with eight successively planted rice crops did not significantly affect rice yieids, $N$ content of the straw or grain, recovery of fertilizer $N$ or organic matter content of the soil. Vields increased with $N$ applications up to over $100 \mathrm{~kg} / \mathrm{ha}$. N contents of the straw and grain also increased irrespective of method of straw disposal. Nitrogen applications did not affect $\mathrm{N}$ or organic matter content of the soil.

\section{INTRODUCTION}

The disposal of rice straw poses practical, technical and economic problems especially in Puerto Rico, where rice is grown continuously throughout the year.

How the straw is handled can affect the use of fertilizer nitrogen. Williams et al. (16) found that burning or plowing under the straw resulted in similar yields of rice and did not affect the $\mathrm{N}$ economy in a field planted to rice for 8 years with $\mathrm{N}$ rates varying from 0 to $135 \mathrm{~kg} /$ ha. Williams et al. (14) working with California rice soils found that adding leguminous green manures increased the decomposition rate of rice straw without tying up $\mathrm{N}$, and that burning the straw had no effect on yields of the first three crops, but reduced yields of the next two crops. Williams et al. (15) found that straw (vetch hay) with a high $\mathrm{N}$ content ( 3.4 to $3.9 \%$ ) increased rice yields, whereas straw with a low $\mathrm{N}$ content $(.45 \%)$ depressed yields. Supplemental $\mathrm{N}$ applied as urea increased yields in the presence of both high and low $\mathrm{N}$ straw. No significant immobilization of the $\mathrm{N}$ was found to result from straw applications. Williams and Frinfrock (13) found that $\mathrm{N}$ from both vetch hay and ammonia were equally effective in increasing rice yields. Acharya (1) found that about six times more $\mathrm{N}$ was immobilized by rice straw decomposing under aerobic than under anaerobic conditions. Guha et al. (4) working with Indian soils found that $\mathrm{N}$ concentrations of 1.7 to $1.9 \%$ in the rice straw were necessary to avoid immobilization of $\mathrm{N}$ under aerobic conditions,

${ }^{1}$ Manuscript submitted to Editorial Board March 29, 1985.

${ }^{2}$ This paper covers work carried out cooperatively between the Agricultural Research Service, USDA and the Agricultural Experiment Station, College of Agricultural Sciences, University of Puerto Rico, Mayagüez Campus.

${ }^{3}$ Research Assistant; Agricultural Experiment Station; and Soil Scientists, Agricultural Research Service, USDA. 
whereas $0.45 \%$ was sufficient under anaerobic conditions. Pal and Broodhent (7) concluded that $\mathrm{N}$ released from straw during decomposition under flooding was lost from the system. Moore et al. (6) reported that $90 \%$ of preflood applications and $95 \%$ of all subsequent inorganic N found in the soil remained as exchangeable $\mathrm{NH}_{4}{ }^{+}$until the flood was removed. Reddy and Patrick (10) found that of the residual fertilizer $\mathrm{N}$ in flooded rice soils, $2.7 \mathrm{~kg} / \mathrm{ha}$ was in the grain, $3.1 \mathrm{~kg}$ was in the straw and 34 to $40 \mathrm{~kg} / \mathrm{ha}$ remained in the soil, and that over two years, 62 to $82 \%$ of the applied $\mathrm{N}$ could be accounted for.

In Puerto Rico, Lozano and Abruña (5) found that the Brazos variety of medium grain rice responded to two applications of $\mathrm{N}$ totalling 112 $\mathrm{kg} / \mathrm{ha}$ with no residual effect on a subsequent rice crop. Silva and VicenteChandler (11) in studies in lysimeter tanks found that $66 \%$ of $50 \mathrm{~kg}$ of $\mathrm{N}$ applied / ha and $50 \%$ of the second $50 \mathrm{~kg}$ increment of $\mathrm{N}$ fertilizer was recovered in the rice plants, including the roots. Patrick and Reddy (8) reported recoveries varying from $75 \%$ to $85 \%$ of the $\mathrm{N}$ applied to a Crowley silt loam soil.

The present study determined the effects of three methods of straw disposal, five levels of fertilizer $\mathrm{N}$, and their interaction on yields and recovery of $\mathrm{N}$ applied to intensively managed rice.

\section{MATERIALS AND METHODS}

The study covered eight consecutive rice crops planted over a 4-year period in a Coloso silty clay (fine, mixed, nonacid, isohyperthermic Aeric Tropic Fluvaquents) at the Gurabo Substation. The upper $30 \mathrm{~cm}$ of soil had a $\mathrm{pH}$ of $6.8,2.3 \%$ organic matter; $20.3,5.8$ and $16 \mathrm{me} / 100 \mathrm{~g}$ of exchangeable $\mathrm{Ca}, \mathrm{Mg}$, and $\mathrm{K}$, respectively; a bulk density of 1.4 , and $25.5 \%$ moisture at field capacity.

Three methods of straw disposal-burning, removal from the plots and incorporating into the soil with a small roto tiller-were compared at 5 $\mathrm{N}$ levels; $0,50,100,150$ and $200 \mathrm{~kg} / \mathrm{ha} / \mathrm{crop}$. Sixty $4 \times 4 \mathrm{~m}$ plots were arranged in a partially balanced block design with treatments replicated four times. Each plot was surrounded by dikes $60 \mathrm{~cm}$ wide and $40 \mathrm{~cm}$ high to prevent movement of $\mathrm{N}$ fertilizer from one plot to another. Ditches were constructed between every two lines of plots and irrigation water was supplied individually to each plot through sections of plastic pipe.

Just prior to planting, $40 \mathrm{~kg}$ of $\mathrm{P}$ (as triple superphosphate), $80 \mathrm{~kg}$ of $\mathrm{K}$ (as $\mathrm{K}_{2} \mathrm{SO}_{4}$ ), and half of the corresponding $\mathrm{N}$ level as $\left(\mathrm{NH}_{4}\right)_{2} \mathrm{SO}_{4}$, was incorporated into the upper $10 \mathrm{~cm}$ of soil. The remaining $\mathrm{N}$ was applied to the flooded plots 6 weeks later.

All plots were seeded to the Brazos variety broadcast at the rate of 100 $\mathrm{kg} / \mathrm{ha}$ and covered with $2 \mathrm{~cm}$ of soil. Weeds were controlled by an 
application of Bolero ${ }^{4}$, a preemergent herbicide, followed by Propanil just prior to permanent flooding 3 weeks after planting. Insects and diseases were controlled by periodic spraying with Malathion and Benomyl, respectively. All plots were kept flooded until 3 weeks before harvesting.

The rice was harvested by cutting the plants about $10 \mathrm{~cm}$ from the ground when the grain had about $20 \%$ moisture. The rough rice was dried to $12 \%$ moisture and the straw was oven dried at $65^{\circ} \mathrm{C}$. Nitrogen content of the grain and straw was determined by the Kjeldahl method.

The upper $10 \mathrm{~cm}$ of soil in each plot was sampled before draining the plots for harvesting the eighth crop and analyzed for nitrates and exchangeable ammonium by the Bremner method (2) and for organic carbon by the Schollenberger method (12).

Analysis of variance was used to determine the effect of method of straw disposal on yields, and regression analysis to determine the effect of $\mathrm{N}$ levels.

After eight consecutive rice crops with the prescribed treatments, a rice crop was grown in all plots with no fertilizer applied to determine the residual effects of the treatments.

\section{RESULTS AND DISCUSSION}

Rice responded strongly to $\mathrm{N}$ applications regardless of the method of straw disposal of more than $100 \mathrm{~kg} / \mathrm{ha} / \mathrm{crop}$, both in average yields for all eight crops (table 1) and yields for the last three crops (fig. 1).

Yields were generally highest when the straw was mixed with the soil and lowest when the straw was removed from the fields, intermediate with burning (fig. 1). These apparent differences, however, were not statistically significant either for average yields of eight crops (table 1) or for the last three crops (table 2).

Some Puerto Rican farmers sell rice straw to feed cattle during the dry season thus making removal profitable. Rice straw has a digestibility of only about $30 \%$ when fed to ruminants, but treatment with ammonium or sodium hydroxide can increase digestibility considerably. Burning causes environmental problems, whereas the presence of rice straw makes land preparation more difficult and can increase the risk of infection for subsequent rice crops.

The unfertilized rice crop grown after the experiment was concluded showed no effect from the previous treatments on yields.

There was no consistent significant effect of method of straw disposal

\footnotetext{
${ }^{1}$ Trade names in this publication are used only to provide specific information. Mention of a trade name does not constitute a warranty of equipment or materials by the USDA or the Agricultural Experiment Station of the University of Puerto Rico, nor is this mention a statement of preference over other equipment or materials.
} 
on $\mathrm{N}$ content of the straw or grain or on recovery of fertilizer $\mathrm{N}$ either for the eight crops or for the last three crops (tables 1 and 2).

Nitrogen in the straw and grain increased, and percentage of fertilizer $\mathrm{N}$ recovered in the plants decreased slightly, with increasing $\mathrm{N}$ levels regardless of method of straw disposal (tables 1 and 2).

After eight consecutive crops, $\mathrm{N}$ in the upper $10 \mathrm{~cm}$ of soil, either as nitrates or as ammonia, was not significantly affected by $N$ rates or

TABLE 1,-Effect of nitrogen rates and method of straw disposal on rice yields and nitrogen recovered in grain and straw. Figures are averages of 8 consecutively planted rice crops

\begin{tabular}{|c|c|c|c|c|c|c|}
\hline \multirow{2}{*}{$\begin{array}{l}\text { Method of straw } \\
\text { disposal }\end{array}$} & \multicolumn{5}{|c|}{ Fertilizer nitrogen applied (kg/ha/crop) } & \multirow{2}{*}{ Mean } \\
\hline & 0 & 56 & 112 & 168 & 224 & \\
\hline \multicolumn{7}{|c|}{ Yields of dry rough rice $(\mathrm{kg} / \mathrm{ha})$} \\
\hline Removed & $3289 \mathrm{~d}^{2}$ & $4157 c$ & $5447 \mathrm{~b}$ & $5683 \mathrm{a}, \mathrm{b}$ & $5796 \mathrm{a}, \mathrm{b}$ & 4874 a \\
\hline Incorporated & $3301 \mathrm{~d}$ & $4508 \mathrm{c}$ & $5535 \mathrm{a}, \mathrm{b}$ & $6013 a, b$ & $6031 \mathrm{a}, \mathrm{b}$ & $5078 \mathrm{a}$ \\
\hline Burned & $3375 \mathrm{~d}$ & $4365 \mathrm{c}$ & $5394 \mathrm{~b}$ & $5770 \mathrm{a}, \mathrm{b}$ & 6179 a & 4997 a \\
\hline Average & $3322 \mathrm{~d}$ & $4343 \mathrm{c}$ & $5459 \mathrm{~b}$ & $5822 \mathrm{a}, \mathrm{b}$ & $6002 \mathrm{a}, \mathrm{b}$ & \\
\hline \multicolumn{7}{|c|}{ Nitrogen contained in the straw (kg/ha) } \\
\hline Removed & $17 \mathrm{f}$ & $23 \mathrm{c}, \mathrm{d}, \mathrm{e}$ & $24 \mathrm{c}, \mathrm{d}$ & $29 \mathrm{~b}$ & $35 \mathrm{a}$ & 26 a \\
\hline Incorporated & $17 \mathrm{f}$ & $20 \mathrm{~d}, \mathrm{e}, \mathrm{f}$ & $27 \mathrm{~b}, \mathrm{c}$ & $30 \mathrm{~b}$ & $37 \mathrm{a}$ & $26 \mathrm{a}$ \\
\hline Burned & $18 \mathrm{f}$ & $20 \mathrm{~d}, \mathrm{e}, \mathrm{f}$ & $28 \mathrm{~b}, \mathrm{c}$ & $28 \mathrm{~b}, \mathrm{c}$ & 35 a & 26 a \\
\hline Average & $17 \mathrm{f}$ & $21 \mathrm{~d}, \mathrm{e}$ & $26 \mathrm{~b}, \mathrm{c}$ & $29 \mathrm{~b}$ & $36 \mathbf{a}$ & \\
\hline \multicolumn{7}{|c|}{ Nitrogen contained in the grain $(\mathrm{kg} / \mathrm{ha})$} \\
\hline Removed & $31 \mathrm{~g}$ & $42 \mathrm{f}$ & $54 \mathrm{e}$ & $58 \mathrm{c}, \mathrm{d}$ & $64 a, b$ & $50 \mathrm{a}$ \\
\hline Incorporated & $32 \mathrm{~g}$ & $45 \mathrm{f}$ & $56 \mathrm{~d}, \mathrm{e}$ & $64 \mathrm{a}, \mathrm{b}$ & $64 \mathrm{a}, \mathrm{b}$ & $52 \mathrm{a}$ \\
\hline Burned & $32 \mathrm{~g}$ & $43 \mathrm{f}$ & $56 \mathrm{~d}, \mathrm{e}$ & $61 \mathrm{~b}, \mathrm{c}$ & $67 \mathrm{a}$ & $52 \mathrm{a}$ \\
\hline Average & $32 \mathrm{~g}$ & $43 \mathrm{f}$ & $55 \mathrm{~d}, \mathrm{e}$ & $61 \mathrm{~b}, \mathrm{c}$ & 65 a & \\
\hline \multicolumn{7}{|c|}{$\begin{array}{l}\text { Percent of fertilizer nitrogen recovered in grain } \\
\text { and straw }\end{array}$} \\
\hline Removed & - & $30 \mathrm{a}$ & $27 \mathrm{a}, \mathrm{b}, \mathrm{c}$ & $23 d$ & $23 \mathrm{~d}$ & 26 a \\
\hline Incorporated & 一 & $29 \mathrm{a}, \mathrm{b}$ & $30 \mathrm{a}$ & $27 \mathrm{a}, \mathrm{b}, \mathrm{c}$ & $23 \mathrm{~d}$ & 27 a \\
\hline Burned & - & $23 \mathrm{~d}$ & $30 \mathrm{a}$ & $23 \mathrm{~d}$ & $23 \mathrm{~d}$ & $25 \mathrm{a}$ \\
\hline Average & & $27 \mathrm{a}, \mathrm{b}, \mathrm{c}$ & $29 \mathrm{a}, \mathrm{b}$ & $24 c, d$ & $23 \mathrm{~d}$ & \\
\hline
\end{tabular}

"Values with one or more letters in common do not differ at the $5 \%$ level (Duncan Multiple Range Test).

method of straw disposal, averaging about $20 \mathrm{~kg} / \mathrm{ha}$ of $\mathrm{N}$ as ammonia and $13 \mathrm{~kg} / \mathrm{ha}$ of $\mathrm{N}$ as nitrates.

After eight rice crops, organic matter content of the upper $10 \mathrm{~cm}$ of soil averaged $2.63,2.71$ and $2.92 \%$, when the rice straw was removed, burned, and incorporated, respectively, but the apparent differences were not statistically significant. Nitrogen rates had no apparent effect on organic matter content of the soil.

It is possible that some of the applied $\mathrm{N}$ was immobilized temporarily in the incorporated straw which could also have caused a more stable 
reduced condition in the soil as it decomposed. Broadbent and Tusneem (3) found that $40 \%$ of $\mathrm{N}$ applied as $\mathrm{NH}_{3}$ to Sacramento soil was lost when no straw was incorporated, whereas losses were small when $\mathrm{N}$ was rapidly immobilized by organic matter. The reduction process in soils is affected by the supply of easily decomposable organic materials (9).

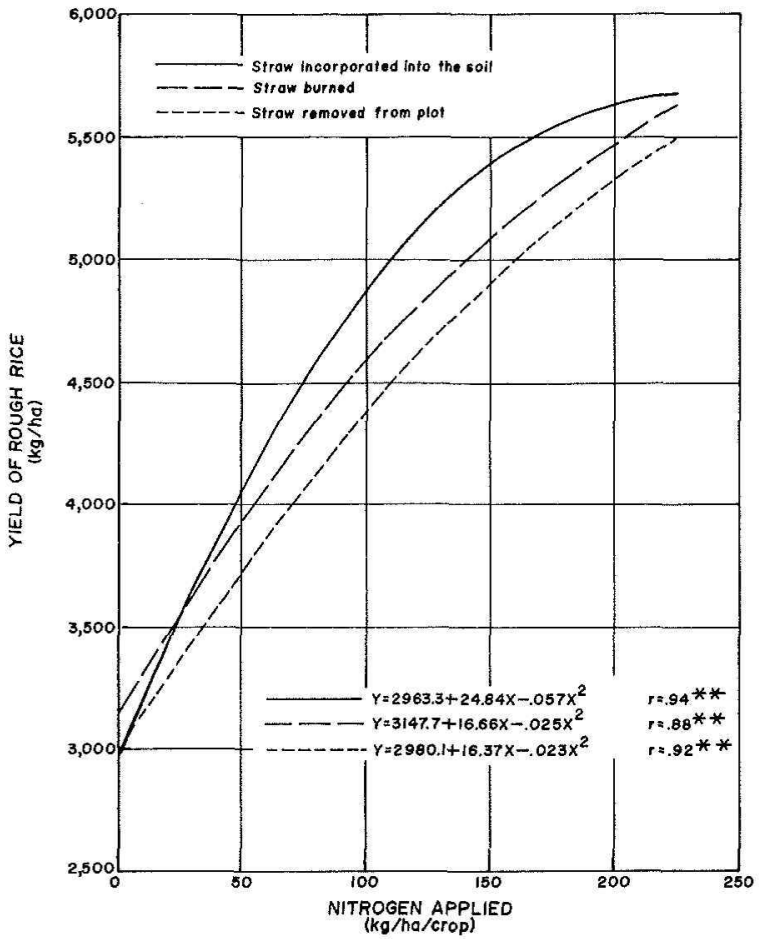

Fia. 1.-Effect of three methods of straw disposal and of nitrogen fertilization on average yields of rice over the last three of eight consecutive crops. 


\section{RESUMEN}

Se realizaron ocho siembras consecutivas de arroz en un estudio en que se variaron las cantidades de nitrógeno y se deshizo de la paja de tres maneras: quemándola, sacándola de las parcelas o incorporándola al suelo.

Aunque los rendimientos más altos se obtuvieron cuando la paja se incorporó al suelo, y los más bajos cuando se sacó, las diferencias no fueron estadisticamente significativas. La manera de deshacerse de la paja

TABLE 2.-Effect of nitrogen rates and method of straw disposal on rice yields and nitrogen recovered in grain and straw during the last three crops

\begin{tabular}{|c|c|c|c|c|c|c|}
\hline \multirow{2}{*}{$\begin{array}{c}\text { Straw disposal } \\
\text { method }\end{array}$} & \multicolumn{5}{|c|}{ Fertilizer nitrogen applied (kg/ha/crop) } & \\
\hline & 0 & 56 & 112 & 168 & 224 & \\
\hline \multicolumn{7}{|c|}{ Grain yields of $12 \%$ moisture rough rice $(\mathrm{kg} / \mathrm{ha})$} \\
\hline Removed & $3049 \mathrm{e}^{1}$ & $3638 \mathrm{~d}$ & $4666 \mathrm{c}$ & $5075 \mathrm{~b}, \mathrm{c}$ & $5463 \mathrm{a}, \mathrm{b}$ & 4378 a \\
\hline Incorporated & 2939 e & $4214 \mathrm{~d}$ & $4969 \mathrm{c}$ & $5565 \mathrm{a}$ & $5446 \mathrm{a}, \mathrm{b}$ & 4626 a \\
\hline Burned & $3134 \mathrm{e}$ & $3944 \mathrm{~d}$ & $4967 c$ & $4963 c$ & $5748 \mathrm{~b}$ & 4551 a \\
\hline Average & 3041 e & $3932 \mathrm{~d}$ & $4868 \mathrm{e}$ & $5201 \mathrm{a}, \mathrm{b}, \mathrm{c}$ & 5552 a & \\
\hline \multicolumn{7}{|c|}{ Nitrogen contained in straw ( $\mathrm{kg} / \mathrm{ha})$} \\
\hline Removed & $16 \mathrm{~h}$ & $21 \mathrm{f}$ & $22 \mathrm{e}, \mathrm{f}$ & $32 \mathrm{~b}$ & $34 \mathrm{a}, \mathrm{b}$ & $25 \mathrm{a}$ \\
\hline Incorporated & $18 \mathrm{~g}, \mathrm{~h}$ & $21 \mathrm{f}$ & $25 \mathrm{~d}$ & $29 \mathrm{c}$ & 36 a & $26 a$ \\
\hline Burned & $20 \mathrm{f}, \mathrm{g}$ & $21 \mathrm{f}$ & $27 \mathrm{c}, \mathrm{d}$ & $29 \mathrm{c}$ & $34 \mathrm{a}, \mathrm{b}$ & $26 a$ \\
\hline Average & $18 \mathrm{~g}, \mathrm{~h}$ & $21 \mathrm{f}$ & $25 \mathrm{e}, \mathrm{f}$ & $30 \mathrm{c}$ & $35 \mathrm{a}$ & \\
\hline \multicolumn{7}{|c|}{ Nitrogen contained in the grain $(\mathrm{kg} / \mathrm{ha})$} \\
\hline Removed & $31 \mathrm{~h}$ & $40 \mathrm{~g}$ & $47 \mathrm{~d}, \mathrm{e}$ & $51 \mathrm{c}, \mathrm{d}$ & $60 \mathrm{a}$ & 46 a \\
\hline Incorporated & $29 \mathrm{~h}$ & $43 \mathrm{~g}$ & $51 \mathrm{c}, \mathrm{d}$ & $58 \mathrm{a}, \mathrm{b}$ & $58 \mathrm{a}, \mathrm{b}$ & 48 a \\
\hline Burned & $31 \mathrm{~h}$ & $41 \mathrm{~g}$ & $54 \mathrm{~b}, \mathrm{c}$ & $52 c$ & $60 \mathrm{a}$ & 48 a \\
\hline Average & $30 \mathrm{~h}$ & $41 \mathrm{~g}$ & $51 \mathrm{c}, \mathrm{d}$ & $54 \mathrm{~b}$ & $59 \mathrm{a}$ & \\
\hline \multicolumn{7}{|c|}{ Nitrogen received in grain and straw (\% of $N$ applied) } \\
\hline Removed & - & $25 \mathrm{~b}$ & $20 \mathrm{~d}$ & $21 \mathrm{c}, \mathrm{d}$ & $21 c, d$ & $22 \mathrm{a}, \mathrm{b}$ \\
\hline Incorporated & - & $30 \mathrm{a}$ & $26 \mathrm{~b}$ & $24 \mathrm{~b}, \mathrm{c}$ & $21 \mathrm{e}, \mathrm{d}$ & $25 \mathrm{a}$ \\
\hline Burned & - & $20 \mathrm{~d}$ & $27 \mathrm{a}, \mathrm{b}$ & $19 \mathrm{~d}$ & $19 \mathrm{~d}$ & $21 \mathrm{~b}, \mathrm{c}$ \\
\hline Average & - & $25 \mathrm{~b}$ & $24 \mathrm{~b}, \mathrm{c}$ & $21 \mathrm{c}, \mathrm{d}$ & $20 d$ & \\
\hline
\end{tabular}

${ }^{1}$ Values with one or more letters in common do not differ at the $5 \%$ level of probability (Duncan Multiple Range Test).

no afectó el contenido en nitrógeno de la paja o del grano, el porcentaje de nitrógeno aplicado como fertilizante que se recobró en las plantas de arroz, o el contenido en materia orgánica del suelo.

La producción de arroz aumentó según aumentó las cantidad de abono nitrogenado hasta más de $100 \mathrm{~kg} / \mathrm{ha}$. El contenido en nitrógeno de la paja y del grano aumentó según se incrementó las cantidad de nitrógeno, mientras que el porcentaje que se recuperó en las plantas de arroz disminuyó. Las aplicaciones de nitrógeno no afectaron el contenido en nitratos, en amoníaco y materia orgánica del suelo. 


\section{LITERATURE CITED}

1. Acharya, C. N., 1935. The anaerobic decomposition of rice straw (Oryza sativa). III. Comparison of the course of decomposition of rice straw under anaerobic, aerobic and partially aerobic conditions, Biochem. J. 29: 528-41.

2. Bremner, J. M., 1965. Inorganic forms of nitrogen. In C. A. Black et al. (Ed), Methods of soil analisis, part 2 Agronomy 9: 1179-237. Am. Soc. Agron. Madison, Wis.

3. Broadbent, F. E. and M. E. Tusneem, 1971. Losses of nitrogen from flooded soils in traces experiments, Soil Sci. Soc. Am. Proc. 35: 922-26.

4. Guha Sica, S. S., S. C. De and H. D. Bhowmich, 1940. Microbial decomposition of plant material. 1. Changes in the constituents of rice straw (Kanak Tara) produced by microorganisms present in the soil suspension under aerobic, anaerobic and waterlogged conditions. Indian J. Agric. Sei. 10: 119-51.

5. Lozano, J. M. and F. Abruña, 1981. Nitrogen rates in single and split applications and yield of flooded rice, J. Agric. Univ. P. R. 65 (11): 35-42.

6. Moore, P. A., J. T. Gilmour and B. R. Wells, 1981. Seasonal patterns of growth and soil nitrogen uptake by rice, Soil Sci. Soc. Am. J. 45: 875-79.

7. Pal, D. and F. E. Broadbent, 1975. Influence of moisture on rice straw decomposition in soils, Soil Sci. Soc. Am. Proc 39 (1) 59-63.

8. Patrick, W. H., Jr. and K. R. Reddy, 1976. Fate of fertilizer nitrogen in a flooded rice soil, Soil Sci. Soc. Am. J. 40:678-81.

9. Ponnamperuma, F. N., 1965. Dynamic aspects of flooded soils and the nutrition of the rice plant. The Mineral Nutrition of the Rice Plant. p. 295-328, John's Hopkins Press, Baltimore,

10. Keddy, K. R. and W. H. Patrick, Jr., 1978. Residual fertilizer nitrogen in a flooded rice soil, Soil Sci. Soc. Am. J. 42: 316-18.

11. Silva, S, and J. Vicente-Chandler, 1984. Nitrogen uptake and growth of irrigated rice as affected by nitrogen rates, J. Agric. Univ. P. R. 68 (4) $387-94$.

12. Schollenberger, C. J., 1945. Determination of soil organie matter, Soil Sci. 59: 56.

13. Williams, W. A, and D. C. Frinfrock, 1962. Effect of placement and time of incorporation of vetch on rice yields, Agric. J. 54: 547-49.

14. - - - L. L. Davis and D. S. Mikkelsen, 1957. Green manuring and crop residue management in rice production, Soil Sci. Soc. Am. Proc. 21: 412-15.

15. — D. S. Mikkelsen, K. E. Mueller and J. E. Ruckman, 1968. Nitrogen inmobilization by rice straw incorporated in lowland rice production, Plant Soil 28:49-60.

16. - M. D. Morse, J. E. Ruckman and F. P. Guerrero, 1972. Rice straw burning vs. incorporation, Calif, Agric, 26 (2) 12-3. 
